\title{
Pengembangan Exchange Trade Fund Syariah Indonesia: Peluang dan Tantangan
}

\author{
Risca Azmiana ${ }^{1}$, Rifqi Muhammad ${ }^{2 *}$ \\ ${ }^{1,2}$ Fakultas Bisnis dan Ekonomika, Universitas Islam Indonesia, Yogyakarta \\ *Email korespondensi: rifqimuhammad@uii.ac.id
}

\begin{abstract}
This paper aims to discuss the opportunities and challenges of developing Sharia Exchange Trade Fund (ETF) investment products in Indonesia. ETF is an investment product in the capital market that collaborates stock and mutual fund products that can collectively be traded on the capital market. This will provide attractive new investment opportunities for investors who are concerned about sharia investment. With the consideration that Indonesia's population is predominantly Muslim, then of course Islamic investment products will attract them. ETFs have the following advantages: easy and flexible process of ownership and transfer, low cost and risk, wide coverage because they are like investing in several portfolios at once, and the process is transparent. In particular, Islamic ETFs have the advantage in the aspect of ensuring product halalness because their portfolios are always monitored by the sharia supervisory board in each investment manager as the manager. On the other hand, Islamic ETFs are faced with challenges related to the low literacy of the Muslim community about investing in the capital market that has sharia products.
\end{abstract}

Keywords: Exchange Traded Fund (ETF), Islamic capital market, mutual fund

Saran sitasi: Anshori, M., \& Shofiyuddin, M. A. (2021). Pengembangan Exchange Trade Fund Syariah Indonesia: Peluang dan Tantangan. Jurnal Ilmiah Ekonomi Islam, 7(01), 55-66. doi:http://dx.doi.org/10.29040/jiei.v7i1.1824

DOI: http://dx.doi.org/10.29040/jiei.v7i1.1824

\section{PENDAHULUAN}

Pertumbuhan ekonomi suatu negara tidak dapat terlepas dari peranan pasar modal. Pasar modal memiliki fungsi sebagai sarana bagi perusahaan untuk mendapatkan pendanaan dari masyarakat (investor). Dana yang didapatkan dari masyarakat (investor) digunakan untuk mengembangkan usaha, melakukan ekspansi bisnis, penambahan modal kerja, serta pasar modal juga merupakan sarana dari masyarakat untuk melakukan investasi pada instrument keuangan (Bursa Efek Indonesia, 2020).

Pada pasar modal terdapat berbagai macam produk investasi. Secara umum investasi cenderung identik dengan saham. Namun, produk investasi yang terdapat pada pasar modal tidak hanya saham. Salah satu produk investasi yang mengalami perkembangan cukup pesat saat ini adalah Exchange Traded Funds $(E T F)$. ETF berasal dari inovasi yang terjadi di pasar modal (Farouk \& Masih, 2016). ETF adalah reksa dana yang berbentuk kontrak investasi kolektif dimana unit penyertaanya diperdagangkan pada Bursa Efek (Bursa Efek Indonesia, 2020a).

Perkembangan ETF secara global mengalami peningkatan yang cukup signifikan. Berdasarkan laporan dari Ernest and Young sejak tahun 2005 pertumbuhan ETF secara global mengalami peningkatan sebesar 21 persen dan diprediksi akan mengalami peningkatan secara terus menerus $(\mathrm{CNBC}$ Indonesia, 2019). ETF di Indonesia mengalami pertumbuhan yang cukup pesat. Berdasarkan catatan dari Otoritas Jasa Keuangan pada tahun 2015 sampai dengan 2019, ETF mengalami pertumbuhan yang pesat, dengan jumlah assets under management pada tahun 2019 sebesar lima belas triliun rupiah. Jika dibandingkan dengan tahun 2015 mengalami peningkatan sebesar 477 persen. Hal ini dikarenakan pertumbuhan produk yang meningkat, serta partisipan yang ingin menerbitkan ETF semakin banyak.

Pertumbuhan keuangan Islam yang dinamis dan kebutuhan produk investasi yang sesuai dengan syariat agama menjadi suatu hal yang dapat 
dipertimbangkan, dengan munculnya ETF yang sesuai dengan syariat Islam. Adanya ETF syariah memberikan peluang untuk investor muslim serta investor lain untuk berinvestasi pada ETF yang sesuai dengan syariah. Perbedaan antara ETF konvensional dengan ETF syariah terletak pada prinsip yang digunakan dalam transaksi serta unsur-unsur yang tidak diperbolehkan. Dalam ETF syariah harus sesuai dengan prinsip syariah. Struktur dari ETF syariah sangat unik jika dibandingkan dengan ETF konvensioanl, dengan komponen yang harus sesuai dengan syariah termasuk dalam menyeleksi stok syariah. Hal ini dikarenakan bahwa ETF syariah membutuhkan kepatuhan yang ketat dari awal proses hingga akhir (Farouk \& Masih, 2016)

Indonesia memiliki pasar modal yang cukup potensial. Dengan jumlah investor yang terus meningkat dari tahun ke tahun. Berdasarkan catatan dari PT Kustodian Sentral Efek Indonesia (KSEI) bahwa total investor pada tahun 2019 yang meliputi investor saham, reksa dana dan surat utang mencapai 2,48 juta per 27 Desember 2019 atau naik sebesar 53,04 persen jika dibandingkan pada tahun 2018 yaitu 1,62 juta investor (Kumparan, 2019). Jumlah investor yang terus bertambah diharapkan produk investasi seperti ETF syariah dapat berkembang dengan cukup pesat. Hal ini disebabkan ETF syariah banyak dikenal oleh masyarakat Indonesia. Dengan Indonesia yang memiliki penduduknya mayoritas beragama Islam ini merupakan tantangan tersendiri untuk mengungkapkan tantangan yang dihadapi oleh ETF syariah dan peluang untuk ETF syariah di Indonesia. Dalam paper ini akan membahas tantangan serta peluang yang akan dihadapi oleh ETF syariah.

\section{METODE PENELITIAN}

Penelitian ini menggunakan pendekatan deskriptif kualitatif dengan menggunakan referensireferensi dan beberapa data sekunder yang diperoleh secara khusus di website Bursa Efek Indonesia selaku entitas yang memfasilitasi penerbitan, penjualan dan perdagangan ETF.

Dengan pertimbangan bahwa ETF merupakan produk investasi yang relatif baru, maka penulis menggunakan informasi-informasi yang bersifat dasar dalam bidang investasi di pasar modal untuk memberikan gambaran ruang lingkup penerbitan ETF yang masuk dalam portfolio investasi yang memiliki kemudahan dan potensi keuntungan dibanding investasi lain.
Analisis yang digunakan dalam penelitian ini adalah dengan melakukan 3 proses utama yaitu reduksi, kategorisasi dan verifikasi data (Neuman \& Djamba, 2014). Reduksi data merupakan proses penelusuran beberapa sumber informasi yang menyajikan pemahamam tentang ETF baik di luar negeri maupun yang dikembangkan di Indonesia. Selanjutnya melakukan proses kategorisasi terhadap informasi yang diperoleh ke dalam beberapa segmen pembahasan untuk memberikan kemudahan bagi peneliti dalam melakukan telaah literatur dan akhirnya melakukan verifikasi terhadap beberapa sumber lain untuk meyakinkan keandalan sumber informasi. Langkah analisis terhadap prospek ETF syariah menjadi fokus utama dengan pertimbangan bahwa portfolio investasi syariah dapat memberikan ketenangan bagi investor tertentu yang memperhatikan sumber asal usul investasi dari sudut pandang syariah.

\section{HASIL DAN PEMBAHASAN}

\subsection{Exchange Traded Funds: Suatu Tinjauan} Teori

ETF merupakan salah satu produk dari reksa dana. ETF merupakan reksa dana yang berbentuk Kontrak Investasi Kolektif yang unit penyertaanya diperdagangkan di Bursa Efek (Bursa Efek Indonesia, 2020a). Dasar dari ETF merupakan reksa dana namun diperdagangkan seperti saham yang terdapat pada Bursa Efek. ETF merupakan penggabungan antara unsur reksa dana dalam hal pengelolaan dana dengan mekanisme saham dalam hal transaksi jual/beli. ETF yang terlah terdaftar pada Bursa Efek dapat dijual dan dibeli kapan saja selama jam bursa masih berlangsung. Namun, ETF dan reksa dana memiliki perbedaan, sebagai berikut:

Tabel 1. Perbedaan ETF dan Stock Mutual Funds

\begin{tabular}{|l|l|l|}
\hline & \multicolumn{1}{|c|}{$\begin{array}{c}\text { Stock Mutual } \\
\text { Funds }\end{array}$} & \multicolumn{1}{|c|}{ ETF } \\
\hline Perdagangan & Via Manajer & - Dealer \\
Melalui & Investasi atau & Partisipan di \\
& Agent Penjual & Pasar Primer \\
& Reksa Dana & Broker \\
& & $\begin{array}{l}\text { manapun di } \\
\text { Pasar } \\
\text { Sekunder }\end{array}$ \\
& & \\
& & \\
\hline $\begin{array}{l}\text { Minimum } \\
\text { Pembelian }\end{array}$ & 1 Unit & Pasar Primer: \\
& & Creation Unit \\
\hline
\end{tabular}


Jurnal Ilmiah Ekonomi Islam, 7(01), 2021, 57

\begin{tabular}{|c|c|c|}
\hline & $\begin{array}{c}\text { Stock Mutual } \\
\text { Funds }\end{array}$ & ETF \\
\hline & & $\begin{array}{l}(=1000 \text { lot }= \\
100.000 \text { Unit }) \\
\text { Pasar Sekuder: } 1 \\
\text { Lot (100 Unit) }\end{array}$ \\
\hline $\begin{array}{l}\text { Biaya } \\
\text { Transaksi }\end{array}$ & $\begin{array}{l}\text { Biaya Pembelian } \\
\text { dan Penjualan } \\
\text { kembali } \\
\text { (umumnya 1\% } \\
\text { hingga 3\%) }\end{array}$ & $\begin{array}{l}\text { Sesuai dengan } \\
\text { biaya komisi } \\
\text { broker/broker fee }\end{array}$ \\
\hline $\begin{array}{l}\text { Risiko } \\
\text { Transaksi }\end{array}$ & $\begin{array}{l}\text { Risiko Manajer } \\
\text { Investasi dari } \\
\text { pengelolaan } \\
\text { portofolio }\end{array}$ & $\begin{array}{l}\text { Dapat dikontrol } \\
\text { (lebih rendah) } \\
\text { karena transaksi } \\
\text { jual/beli ETF } \\
\text { dapat dilakukan } \\
\text { setiap saat } \\
\text { selama jam bursa } \\
\text { berlangsung. }\end{array}$ \\
\hline $\begin{array}{l}\text { Nilai Aktiva } \\
\text { Bersih per } \\
\text { Unit } \\
\text { Penyertaan } \\
\text { (NAB/UP) }\end{array}$ & $\begin{array}{l}\text { Perhitungan } \\
\text { NAB/UP } \\
\text { dilakukan satu kali } \\
\text { setelah penutupan } \\
\text { jam Perdagangan } \\
\text { di Bursa Efek } \\
\text { Indonesia }\end{array}$ & $\begin{array}{l}\text { Perhitungan } \\
\text { indikasi } \\
\text { NAB/UP } \\
\text { (iNAV) } \\
\text { dilakukan setiap } \\
\text { saat selama jam } \\
\text { perdagangan } \\
\text { Bursa Efek } \\
\text { Indonesia } \\
\end{array}$ \\
\hline Harga & Akhir hari & Real time \\
\hline Underlying & Saham & Indeks Acuan \\
\hline Settlement & $\begin{array}{l}\mathrm{T}+7 \text { (tujuh hari } \\
\text { setelah transaksi } \\
\text { dilakukan) }\end{array}$ & $\begin{array}{l}\mathrm{T}+2 \text { (dua hari } \\
\text { setelah transaksi } \\
\text { dilakukan) }\end{array}$ \\
\hline $\begin{array}{l}\text { Dealer } \\
\text { Partisipan }\end{array}$ & Tidak ada & Ada \\
\hline
\end{tabular}

Sumber: Bursa Efek Indonesia (2020b)

Dalam transaksi jual/beli ETF terdapat pihak-pihak yang terlibat, antara lain: (1) Manajer Investasi; (2) Bank Kustodian; (3) Dealer Partisipan; (4) Sponsor; dan (5) Investor. Dealer Partisipan merupakan anggota dari Bursa Efek yang melakukan penjualan atau pembelian unit penyertaan yang bekerjasama dengan manajer investasi. Sedangkan, sponsor adalah pihak yang melakukan penyertaan dalam bentuk uang atau efek. Tujuan investasi pada ETF yaitu diversifikasi dan fleksibilitas. Tujuan diversifikasi adalah untuk melakukan diversifikasi secara otomatis atas beberapa saham unggulan dalam sekali order. Namun, dengan memanfaatkan fleksibilitas jual/beli

yang tinggi, karena dapat langsung melakukan pembelian maupun penjualan ETF selama jam bursa berlangsung selayaknya saham. Ada beberapa keuntungan jika melakukan investasi pada ETF, sebagai berikut:

Tabel 2. Keuntungan ETF

\begin{tabular}{|l|l|}
\hline $\begin{array}{l}\text { Mudah dan } \\
\text { Fleksibel }\end{array}$ & $\begin{array}{l}\text { Dapat dibeli dan dijual kapanpun } \\
\text { selama jam perdagangan seperti } \\
\text { layaknya saham. }\end{array}$ \\
\hline $\begin{array}{l}\text { Rendah Biaya } \\
\text { dan Risiko }\end{array}$ & $\begin{array}{l}\text { Management fee relative lebih } \\
\text { rendah dibandingkan Reksa } \\
\text { Dana. }\end{array}$ \\
& $\begin{array}{l}\text { Biaya Transaksi ETF di pasar } \\
\text { sekunder sesuai dengan komisi } \\
\text { broker. }\end{array}$ \\
\cline { 2 - 2 } & $\begin{array}{l}\text { Risiko rendah karena likuiditas } \\
\text { terjamin }\end{array}$ \\
\hline Cakupan Luas & $\begin{array}{l}\text { Ketika memiliki 1 ETF } \\
\text { memiliki puluhan saham-saham } \\
\text { unggulan. ETF yang ditawarkan } \\
\text { juga variatif. }\end{array}$ \\
\hline Transparan & $\begin{array}{l}\text { Informasi mengenai ETF dan } \\
\text { saham-sahamnya dapat diakses } \\
\text { kapanpun dan dimanapun. }\end{array}$ \\
\hline
\end{tabular}

Sumber: Bursa Efek Indonesia (2020b)

Tujuan dari ETF adalah untuk mengetahui kinerja dari suatu indeks. Kinerja dari ETF dapat terlihat dari NAV dan harga saham. Untuk mereplikasi indeks, ETF dapat dibagi menjadi ETF replikasi fisik dan ETF replikasi derivatif (Barclays, 2019). Dalam ETF yang mereplikasi secara fisik akan membeli aset yang sama dengan indeks replikasi. Ada dua teknik pelacakan fisik yaitu replikasi secara penuh dan replikasi sampel (optimisasi) / replikasi parsial. Pada teknik replikasi penuh semua aset yang berada pada indeks memiliki nilai sama dengan nilai dalam indeks. Proses ini akan membeli semua komponen dari indeks. Untuk replikasi sampel/replikasi parsial. Semua aset pada indeks tidak sepenuhnya dimiliki, hal ini dikarenakan replikasi yang dilakukan secara penuh menjadi kurang efisien dan mahal. Ketika menggunakan pendekatan optimisasi, manajer (investasi) akan membeli sampel dari suatu indeks yang bertujuan untuk mereplikasi kinerjanya. Pendekatan ini umumnya digunakan dimana suatu indeks yang dilacak terdiri dari sejumlah besar saham atau obligasi, yang kemungkinan beberapa diantara saham atau obligasi tersebut tidak likuid. Pengambilan sampel akan berfokus pada stock terbesar dan likuid 
dalam indeks, hal ini dilakukan untuk mengurangi biaya transaksi. Ketika mengalami kesulitan untuk membeli semua saham dalam indeks, beberapa dana pasif akan cenderung menginvestasi dalam sampel indeks yang umumnya mewakili keseluruhan indeks.

ETF replikasi derivatif dilakukan untuk memberikan kinerja indeks menggunakan kontrak derivatif (total return indeks swaps) dengan bank investasi sebagai partner. Berdasarkan perjanjian swap, bahwa rekanan memiliki tugas untuk membayar pengembalian indeks kepada penyedia ETF (umumnya ditentukan oleh rekanan swap). ETF replikasi turunan juga disebut dengan ETF synthetic. ETF synthetic memiliki risiko yang lebih besar jika dibandingkan dengan ETF yang direplikasi secara fisik. Hal ini dikarenakan adanya "counterparty risk" yang dapat diartikan bahwa jika bank investasi tidak dapat memenuhi kewajibannya, maka bank investasi akan melakukan menjual swaps ke ETF sehingga pihak yang memiliki hal tersebut akan mengalami kehilangan. Pihak yang melakukan penjualan kontrak swap harus dapat memberikan jaminan untuk mengurangi risiko. Namun, ETF dengan replikasi fisik lebih mudah untuk dipahami dan tidak adanya risiko yang tersembunyi, sehingga lebih cocok untuk investor individu (Barclays, 2019).

ETF dikelola dengan dua cara yaitu pasif dan aktif. ETF pasif, manajer (investasi) bertugas mengawasi ETF dengan pendekatan "hands-off" yakni memastikan ETF mengiikuti indeks, sehingga manajer (investasi) tidak akan melakukan intervensi jika indeks menjadi lebih buruk. Dengan demikian, dominasi investor yang melacak indeks disebut "pasif" karena tidak ada pengawasan atau dipandu oleh manajer (investasi). Sedangkan, pada ETF aktif, manajer (investasi) akan berusaha untuk mengungguli indeks yang ditunjuk. Namun, pada ETF aktif tidak menjamin kinerja yang baik, pada sewaktu-waktu ETF dapat lebih baik dibandingkan dengan indeksnya atau dapat lebih buruk.

ETF terdiri dari beberapa jenis, yaitu: (1) ETF Indeks; (2) ETF Obligasi; (3) ETF Komoditas; dan (4) ETF Mata Uang Asing (Bursa Efek Indonesia ,2020d). Pada umumnya sebagian besar ETF berupaya untuk melacak kinerja indeks. Ada dua jenis indeks, yaitu: indeks yang melacak pasar secara keseluruhan, contohnya seperti indeks S\&P dan indeks yang melacak "subset" target pada keseluruhan pasar, seperti saham dengan pertumbuhan yang kecil atau besar nilai dari saham. Namun, terdapat juga indeks pada obligasi, komoditas, dan mata uang.

ETF berbasis indeks akan berupaya untuk mendapatkan pengembalian dari pasar yang ingin diikuti dan mengurangi biaya. Pada ETF yang berbasis indeks memiliki kekurangan yaitu ETF indeks tidak mampu melacak underlying index; umumnya terjadi kesalahan pada pelacakan, adanya perbedaan antara harga pasar ETF dan nilai aset bersih dari dana tersebut. Indeks dirancang untuk mengukur kemungkinan terdekat dari nilai pasar keuangan atau dari segmen pasar tersebut. Indeks umumnya terdiri dari sekelompok saham, obligasi, komoditas atau aset lainnya yang dimana tingkat harga keseluruhan, risiko dan pengembaliannya digunakan sebagai ukuran standar pada seluruh dunia. Indeks yang terdapat pada pasar mewakilkan peluang yang dapat dipilih oleh investor dengan bobot sebenarnya.

ETF obligasi adalah salah satu jenis ETF yang secara ekslusif melakukan investasi pada obligasi. ETF obligasi tidak jauh berbeda dengan Reksa Dana obligasi dikarenakan produk investasi tersebut menggunakan portofolio dengan strategi yang berbeda. ETF obligasi dikelola secara pasif dan diperdagangkan sama seperti ETF saham pada Bursa Efek. Adanya hal ini akan meningkatkan stabilitas pasar dan menambah likuiditas serta transparansi pada periode krisis. ETF obligasi memiliki beberapa kesamaan dengan obligasi individual termasuk pembayaran kupon reguler. Salah satu manfaat memiliki obligasi adalah menerima pembayaran tetap sesuai dengan jadwal yang telah ditetapkan. Pada obligasi jadwal pembayaran terjadi setiap enam bulan, namun pada ETF obligasi, aset akan memiliki jatuh tempo yang berbeda, sehingga pada waktu tertentu beberapa obligasi dalam portofolio akan mengalami jatuh tempo untuk pembayaran kupon. Dikarenakan hal ini ETF obligasi membayar bunga setiap bulan dengan nilai kupon yang berbeda. Ini menyebabkan aset dalam ETF obligasi akan terus mengalami perubahan dan tidak mengalami jatuh tempo. Sedangkan, obligasi akan dibeli dan dijual dikarenakan kadaluwarsa atau usianya lebih dari yang ditargetkan.

ETF komoditas akan berinvestasi pada komoditas fisik, seperti barang pertanian, sumber daya alam, dan logam mulia. Umumnya ETF komoditas berfokus pada komoditas tinggal hingga penyimpanan fisik atau fokus pada investasi kontrak berjangka. Pada ETF komoditas lainnya berupaya melacak 
kinerja dari indeks komoditas yang terdiri dari banyaknya komoditas individu menggunakan kombinasi penyimpanan fisik dan posisi derivatif. Ketika seorang investor membeli ETF komoditas, investor tersebut umumnya tidak memiliki asset fisik, namun investor memiliki kumpulan kontrak yang komoditas tersebut. ETF komoditas umumnya menggunakan leverage yang menggunakan kontrak derivatif, kemungkinan investor memiliki uang tunai yang tidak diinvestasikan, yang mungkin akan digunakan untuk membeli sekuritas atau aset lainnya. Pada ETF mata uang asing dirancang untuk melacak kinerja mata uang di pasar valutang asing terhadap dolar AS atau sekumpulang mata uang. Ada beberapa metode yang digunakan yaitu setoran tunai, utang jangka pendek dalam mata uang dan kontrak berjangka (swap). ETF mata uang asing adalah perdagangan spekulatif pada nilai tukar spot.

Gambar 1 merupakan skema penerbitan ETF. Penerbitan ETF dimulai dengan adanya manajer investasi yang menjadi sponsor penerbitannya dengan melibatkan beberapa dealer partisipan yang memiliki komitmen untuk membantu proses pemasaran produk ETF. Secara khusus, dealer partisipan adalah anggota bursa efek yang bekerja sama dengan manajer investasi pengelola ETF untuk melakukan penjualan atau pembelian unit penyertaan ETF. Saat ini ada 6 dealer partisipan yang terdaftar yaitu: Bahana Sekuritas, Mandiri Sekuritas, Sinarmas Sekuritas,

Indopremier Sekuritas, dan Panin Sekuritas. SKEMS FENERTTAN ET

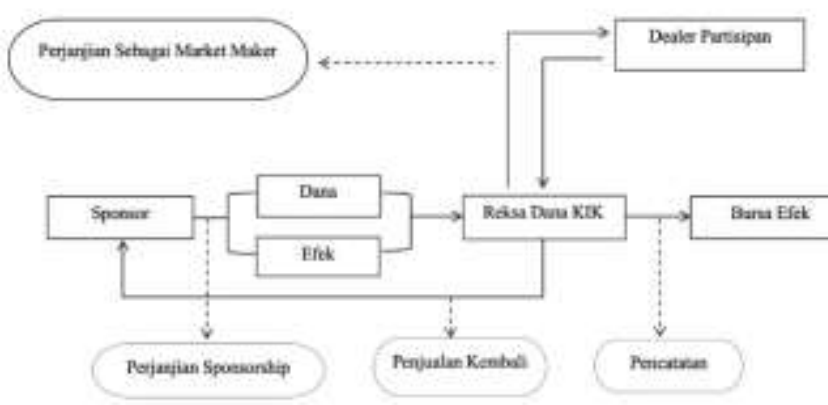

Gambar 1. Skema Penerbitan ETF Sumber: Bursa Efek Indonesia (2020d)
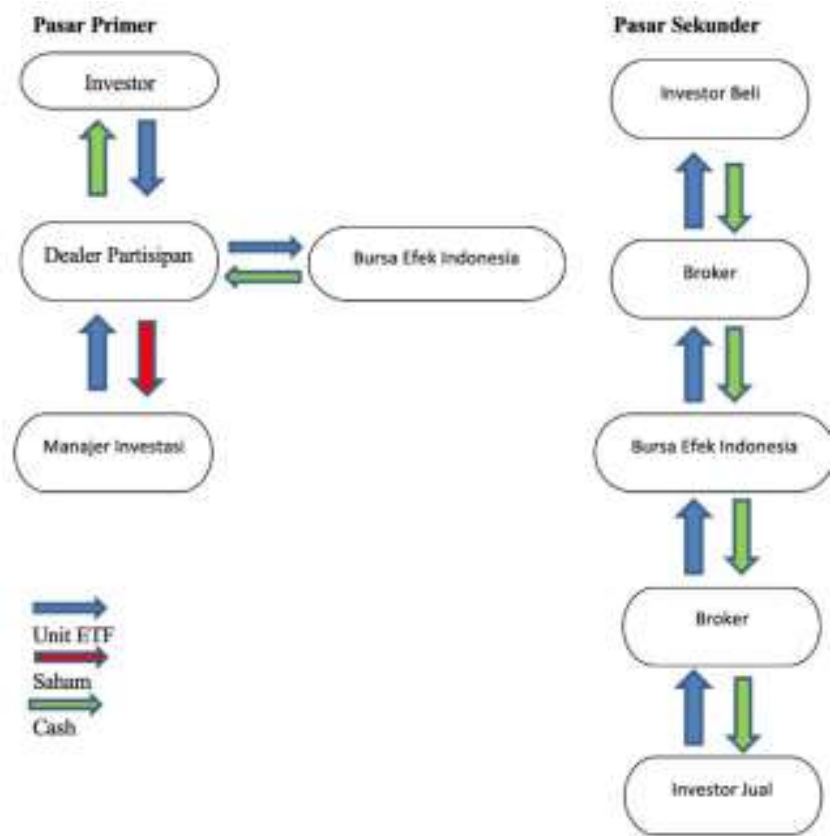

Gambar 2. Skema Transaksi Pasar Premier dan Sekunder

Sumber: Bursa Efek Indonesia (2020a)

Tabel 3. Jumlah ETF di Bursa Efek Indonesia

\begin{tabular}{|c|l|l|c|c|l||}
\hline No. & Kode & \multicolumn{1}{|c|}{ Nama } & $\begin{array}{l}\text { Tanggal } \\
\text { Pencatatan }\end{array}$ & Underlying & Manajer Investasi \\
\hline 1. & R-ABFII & $\begin{array}{l}\text { Reksa Dana Asian Bond Fund - } \\
\text { Indoensia Bond Index Fund }\end{array}$ & 18-Dec-07 & Obligasi & $\begin{array}{l}\text { PT Bahana TCW } \\
\text { Investment Management }\end{array}$ \\
\hline 2. & R-LQ45X & Reksa Dana Premier ETF LQ-45 & 18 -Dec-07 & Saham & $\begin{array}{l}\text { PT Indo Premier } \\
\text { Invetment Management }\end{array}$ \\
\hline 3. & XIIT & $\begin{array}{l}\text { Reksa Dana Premier ETF } \\
\text { IDX30 }\end{array}$ & $30-$ Oct-12 & Saham & $\begin{array}{l}\text { PT Indo Premier } \\
\text { Invetment Management }\end{array}$ \\
\hline 4. & XIIC & $\begin{array}{l}\text { Reksa Dana Premier ETF } \\
\text { Indonesia Consumer }\end{array}$ & $30-$ Apr-13 & Saham & $\begin{array}{l}\text { PT Indo Premier } \\
\text { Invetment Management }\end{array}$ \\
\hline 5. & $\begin{array}{l}\text { XIJI } \\
\text { (Syariah) }\end{array}$ & $\begin{array}{l}\text { Reksa Dana Syariah Premier } \\
\text { ETF JII }\end{array}$ & $30-$ Apr-13 & Saham & $\begin{array}{l}\text { PT Indo Premier } \\
\text { Invetment Management }\end{array}$ \\
\hline 6. & $\begin{array}{l}\text { XISI } \\
\text { Reksa Dana Premier ETF }\end{array}$ & 06-Mar-14 & Saham & $\begin{array}{l}\text { PT Indo Premier } \\
\text { Invetment Management }\end{array}$ \\
\hline
\end{tabular}


Jurnal Ilmiah Ekonomi Islam, 7(01), 2021, 60

\begin{tabular}{|c|c|c|c|c|c|}
\hline No. & Kode & Nama & $\begin{array}{c}\text { Tanggal } \\
\text { Pencatatan }\end{array}$ & Underlying & Manajer Investasi \\
\hline 7. & XISR & $\begin{array}{l}\text { Reksa Dana Premier ETF SRI- } \\
\text { KEHATI }\end{array}$ & 26-Sep-14 & Saham & $\begin{array}{l}\text { PT Indo Premier } \\
\text { Invetment Management }\end{array}$ \\
\hline 8. & XIIF & $\begin{array}{l}\text { Reksa Dana Premier ETF } \\
\text { Indonesia Financial }\end{array}$ & 19-Nov-14 & Saham & $\begin{array}{l}\text { PT Indo Premier } \\
\text { Invetment Management }\end{array}$ \\
\hline 9. & XISC & $\begin{array}{l}\text { Reksa Dana Premier ETF } \\
\text { Indonesia State-Owned } \\
\text { Companies }\end{array}$ & $01-$ Oct-15 & Saham & $\begin{array}{l}\text { PT Indo Premier } \\
\text { Invetment Management }\end{array}$ \\
\hline 10. & XPLQ & $\begin{array}{l}\text { Reksa Dana Pinnacle Enchanced } \\
\text { Liquid ETF }\end{array}$ & 15-Aug-16 & Saham & $\begin{array}{l}\text { PT Pinnacle Persada } \\
\text { Investama }\end{array}$ \\
\hline 11. & XISB & $\begin{array}{l}\text { Reksa Dana Premier ETF } \\
\text { Indonesia Sovereign Bonds }\end{array}$ & 02-Feb-17 & Obligasi & $\begin{array}{l}\text { PT Indo Premier } \\
\text { Invetment Management }\end{array}$ \\
\hline 12. & XPDV & $\begin{array}{l}\text { Reksa Dana Pinnacle Core High } \\
\text { Dividend ETF }\end{array}$ & 09-Jun-17 & Saham & $\begin{array}{l}\text { PT Pinnacle Persada } \\
\text { Investama }\end{array}$ \\
\hline 13. & XPLC & $\begin{array}{l}\text { Reksa Dana Pinnacle Indonesia } \\
\text { Large-Cap ETF }\end{array}$ & 14-Jun-17 & Saham & $\begin{array}{l}\text { PT Pinnacle Persada } \\
\text { Investama }\end{array}$ \\
\hline 14. & $\begin{array}{l}\text { XPES } \\
\text { (Syariah) }\end{array}$ & $\begin{array}{l}\text { Reksa Dana Syariah Pinnacle } \\
\text { Enchanced Sharia ETF }\end{array}$ & 12-Oct-17 & Saham & $\begin{array}{l}\text { PT Pinnacle Persada } \\
\text { Investama }\end{array}$ \\
\hline 15. & XPSG & $\begin{array}{l}\text { Reksa Dana Pinnacle Indonesia } \\
\text { ESG ETF }\end{array}$ & 02-Feb-18 & Saham & $\begin{array}{l}\text { PT Pinnacle Persada } \\
\text { Investama }\end{array}$ \\
\hline 16. & XBLQ & $\begin{array}{l}\text { Reksa Dana Batavia Samrt } \\
\text { Liquid ETF }\end{array}$ & 10-Apr-18 & Saham & $\begin{array}{l}\text { PT Batavia Properindo } \\
\text { Aset Manajemen }\end{array}$ \\
\hline 17. & XDIF & $\begin{array}{l}\text { Reksa Dana Danareksa ETF } \\
\text { Indonesia Top } 40\end{array}$ & 24-Apr-18 & Saham & $\begin{array}{l}\text { PT Danareksa Investment } \\
\text { Management }\end{array}$ \\
\hline 18. & XBNI & $\begin{array}{l}\text { Reksa Dana Indeks BNI AM } \\
\text { Nusantara ETF MSCI Indonesia } \\
\text { Equity Index }\end{array}$ & 23-May-18 & Saham & $\begin{array}{l}\text { PT BNI Assets } \\
\text { Management }\end{array}$ \\
\hline 19. & XPID & $\begin{array}{l}\text { Reksa Dana Indeks Pinnacle } \\
\text { IDX30 ETF }\end{array}$ & 30-May-18 & Saham & $\begin{array}{l}\text { PT Pinnacle Persada } \\
\text { Investama }\end{array}$ \\
\hline 20. & XMTS & $\begin{array}{l}\text { Reksa Dana ETF MNC36 } \\
\text { Likuid }\end{array}$ & 29-Aug-18 & Saham & $\begin{array}{l}\text { PT MNC Assets } \\
\text { Management }\end{array}$ \\
\hline 21. & XPFT & $\begin{array}{l}\text { Reksa Dana Indeks Pinnacle } \\
\text { FTSE Indonesia ETF }\end{array}$ & 10-Sep-18 & Saham & $\begin{array}{l}\text { PT Pinnacle Persada } \\
\text { Investama }\end{array}$ \\
\hline 22. & XSBC & $\begin{array}{l}\text { Reksa Dana Indeks Simas ETF } \\
\text { IDX30 }\end{array}$ & 12-Sep-18 & Saham & $\begin{array}{l}\text { PT Sinarmas Assets } \\
\text { Management }\end{array}$ \\
\hline 23. & XIHD & $\begin{array}{l}\text { Reksa Dana Premier ETF IDX } \\
\text { High Dividend } 20\end{array}$ & 18-Dec-18 & Saham & $\begin{array}{l}\text { PT Indo Premier } \\
\text { Invetment Management }\end{array}$ \\
\hline 24. & XIPI & $\begin{array}{l}\text { Reksa Dana Indeks Premier ETF } \\
\text { Pefindo i-Grade }\end{array}$ & 21-Dec-18 & Saham & $\begin{array}{l}\text { PT Indo Premier } \\
\text { Invetment Management }\end{array}$ \\
\hline 25. & XBID & $\begin{array}{l}\text { Reksa Dana Indeks Batavia } \\
\text { IDX30 ETF }\end{array}$ & 19-Feb-19 & Saham & $\begin{array}{l}\text { PT Batavia Prosperindo } \\
\text { Aset Manajemen }\end{array}$ \\
\hline 26. & XBSK & $\begin{array}{l}\text { Reksa Dana Indeks Batavia SRI- } \\
\text { KEHATI ETF }\end{array}$ & 22-Mar-19 & Saham & $\begin{array}{l}\text { PT Batavia Prosperindo } \\
\text { Aset Manajemen }\end{array}$ \\
\hline 27. & XPMI & $\begin{array}{l}\text { Reksa Dana Indeks ETF Philip } \\
\text { MSCI Indonesia Equity Index }\end{array}$ & 22-Apr-19 & Saham & $\begin{array}{l}\text { PT Philip Asset } \\
\text { Management }\end{array}$ \\
\hline 28. & XPTD & $\begin{array}{l}\text { Reksa Dana Indeks Panin ETF } \\
\text { IDX30 Dinamis }\end{array}$ & 27-May-19 & Saham & $\begin{array}{l}\text { PT Panin Asset } \\
\text { Management }\end{array}$ \\
\hline
\end{tabular}


Jurnal Ilmiah Ekonomi Islam, 7(01), 2021, 61

\begin{tabular}{|c|c|c|c|c|c|}
\hline No. & Kode & Nama & $\begin{array}{c}\text { Tanggal } \\
\text { Pencatatan }\end{array}$ & Underlying & Manajer Investasi \\
\hline 29. & XAQA & $\begin{array}{l}\text { Reksa Dana Ashmore ETF } \\
\text { LQ45 Alpha }\end{array}$ & 12-JuL-19 & Saham & $\begin{array}{l}\text { PT Ashmore Asset } \\
\text { Management Indonesia }\end{array}$ \\
\hline 30. & XMIG & $\begin{array}{l}\text { Reksa Dana Indeks Majoris } \\
\text { Pefindo i-Grade ETF Indonesia }\end{array}$ & 25-Jul-19 & Saham & $\begin{array}{l}\text { PT Majoris Asset } \\
\text { Management }\end{array}$ \\
\hline 31. & $\begin{array}{l}\text { XSSI } \\
\text { (Syariah) }\end{array}$ & $\begin{array}{l}\text { Reksa Dana Syariah Indeks } \\
\text { Simas ETF JII }\end{array}$ & 17-Sep-19 & Saham & $\begin{array}{l}\text { PT Sinarmas Asset } \\
\text { Management }\end{array}$ \\
\hline 32. & XPCR & $\begin{array}{l}\text { Reksa Dana PNM ETF Core } \\
\text { LQ45 }\end{array}$ & 30-Sep-19 & Saham & $\begin{array}{l}\text { PT PNM Investrment } \\
\text { Management }\end{array}$ \\
\hline 33. & XBIN & $\begin{array}{l}\text { Reksa Dana Indeks Bahana ETF } \\
\text { Bisnis-27 }\end{array}$ & 01-Oct-19 & Saham & $\begin{array}{l}\text { PT Bahana TCW } \\
\text { Investment Management }\end{array}$ \\
\hline 34. & XAFA & $\begin{array}{l}\text { Reksa Dana Avrist ETF Fixed } \\
\text { Rate Bond I }\end{array}$ & 18-Oct-19 & Obligasi & $\begin{array}{l}\text { PT Avrist Asset } \\
\text { Management }\end{array}$ \\
\hline 35 & XASG & $\begin{array}{l}\text { Reksa Dana Indeks Aurora ETF } \\
\text { FTSE Indonesia ESG }\end{array}$ & $25-$ Oct-19 & Saham & $\begin{array}{l}\text { PT Aurora Asset } \\
\text { Management }\end{array}$ \\
\hline 36 & XKIV & $\begin{array}{l}\text { Reksa Dana Indeks KISI IDX } \\
\text { Value30 ETF }\end{array}$ & 12-Nov-19 & Saham & $\begin{array}{l}\text { PT KISI Assets } \\
\text { Management }\end{array}$ \\
\hline 37 & XCLQ & $\begin{array}{l}\text { Reksa Dana Indeks Cipta ETF } \\
\text { Index LQ45 }\end{array}$ & 27-Nov-19 & Saham & $\begin{array}{l}\text { PT Ciptadana Asset } \\
\text { Management }\end{array}$ \\
\hline 38 & XNVE & $\begin{array}{l}\text { Reksa Dana Indeks Nusadana } \\
\text { ETF IDX Value } 30\end{array}$ & 05-Des-19 & Saham & $\begin{array}{l}\text { PT Nusadana Investama } \\
\text { Indonesia }\end{array}$ \\
\hline 39 & XBES & $\begin{array}{l}\text { Reksa Dana Indeks BNI-AM } \\
\text { ETF MSCI ESG Leaders } \\
\text { Indonesia }\end{array}$ & 09-Jan-20 & Saham & $\begin{array}{l}\text { PT BNI Asset } \\
\text { Management }\end{array}$ \\
\hline 40 & XSRI & $\begin{array}{l}\text { Reksa Dana Indeks Star ETF } \\
\text { SRI-KEHATI }\end{array}$ & 31-Jan-20 & Saham & $\begin{array}{l}\text { PT Surya Timur Alam } \\
\text { Raya }\end{array}$ \\
\hline 41 & XIML & $\begin{array}{l}\text { Reksa Dana Indeks Premier ETF } \\
\text { MSCI Indonesia Larger Cap }\end{array}$ & 04-Mar-20 & Saham & $\begin{array}{l}\text { PT Indo Premier } \\
\text { Invetment Management }\end{array}$ \\
\hline 42 & XSMU & $\begin{array}{l}\text { Reksa Dana Indeks Syailendra } \\
\text { ETF MSCI Indonesia ESG } \\
\text { Universal Index }\end{array}$ & 05-May-20 & Saham & PT Syailendra Capital \\
\hline 43 & $\overline{X S S K}$ & $\begin{array}{l}\text { Reksa Dana SAM ETF SRI- } \\
\text { KEHATI }\end{array}$ & 14-May-20 & Saham & $\begin{array}{l}\text { PT Samuel Asset } \\
\text { Manajemen }\end{array}$ \\
\hline 44 & XILV & $\begin{array}{l}\text { Reksa Dana Index Insight ETF } \\
\text { FTSE Indonesia Low Volatility } \\
\text { Factor Index }\end{array}$ & 11-Jun-20 & Saham & $\begin{array}{l}\text { PT Insight Investment } \\
\text { Management }\end{array}$ \\
\hline 45 & XIID & $\begin{array}{l}\text { Reksa Dana Indeks Premier ETF } \\
\text { Index IDX30 }\end{array}$ & 23-Jun-20 & Saham & $\begin{array}{l}\text { PT Indo Premier } \\
\text { Invetment Management }\end{array}$ \\
\hline
\end{tabular}

Sumber: Bursa Efek Indonesia (2020c)

ETF di Indonesia diatur dalam Peraturan Otoritas Jasa Keuangan Nomor 49/POJK.04/2015 tentang Reksa Dana Berbentuk Kontrak Investasi Kolektif yang Unit Penyertaannya diperdagangkan di Bursa Efek. Namun, ada beberapa peraturan pendukung untuk ETF yaitu: (i) Peraturan Otoritas Jasa Keuangan Nomor 47/POJK.04/2015 tentang Pedoman Pengumuman Harian Nilai Aktiva Bersih Reksa Dana
Terbuka; (ii) Peraturan Otoritas Jasa keuangan Nomor 48/POJK.04/2015 tentang Pedoman Pengelolaan Reksa Dana Terproteksi, Reksa Dana Dengan Penjaminan, dan Reksa Dana indeks; (iii) Peraturan IV.B.2.- Keputusan Ketua Badan Pengawas Pasar Modal dan Lembanga Keuangan Nomor Kep428/BL/2007 Tentang Pedoman Kontrak Reksa Dana Berbentuk Kontrak Investasi Kolektif; (iv) Peraturan 
III.F tentang Pelaporan Dealer Partisipan; (v) Peraturan II.C tentang Pancatatan dan Perdagangan ETF; dan (vi) Peraturan IV.D.6 tentang Short Selling oleh Perusahaan Efek (Bursa Efek Indonesia, 2020b).

\subsection{ETF:Suatu Tinjauan Syariah}

Berdasarkan Laporan Perkembangan Keuangan Syariah Indonesia Tahun 2018, pertumbuhan pasar modal syariah dapat terlihat dari nilai outstanding sukuk korporasi pada tahun 2018 sebesar Rp. 21,3 Triliun, mengalami peningkatan sebesar $35,32 \%$ jika dibandingkan dengan tahun 2017. Hal lain juga dapat dilihat dari total NAB reksa dana syariah yang meningkat menjadi Rp. 34,49 Triliun pada tahun 2018. Jika dilihat dari sisi investor yang melakukan investasi pada efek syariah berupa saham, sukuk, dan reksa dana syariah mengalami peningkatan sebesar 401.516 investor tahun 2018. Peningkatan jumlah investor tersebut membuat kebutuhan akan produk investasi yang sesuai syariat agama Islam dibutuhkan. Produk investasi yang mengalami pertumbuhan yang signifikan adalah Exhange Traded Funds. Namun, dengan kebutuhan investor yang menginginkan ETF yang sesuai dengan syariat Islam merupakan tantangan tersendiri untuk mengembangkan ETF syariah terutama di Indonesia. Target pasar dari ETF syariah merupakan investor muslim.

Menurut Bursa Efek Indonesia (2020a) ETF syariah adalah salah bentuk reksa dana yang memenuhi prinsip-prinsip syariah di pasar modal dimana unit penyertaannya dicatatkan dan ditransaksikan seperti saham syariah di Bursa Efek. Dikarenakan ETF syariah berbentuk reksa dana maka dalam penerbitan harus sesuai dengan Peraturan Otoritas Jasa Keuangan No. 19/POJK.14/2015 tentang penerbitan dan persyaratan reksa dana syariah. Dalam proses transaksi jual beli, ETF syariah harus dapat memenuhi prinsip-prinsip syariah. Investor yang akan melakukan transaksi jual beli ETF syariah harus melalui anggota bursa yang memiliki Syariah Online Trading System (SOTS). Syariah online trading system adalah sistem transaksi saham syariah secara online yang memenuhi prinsip-prinsip syariah di pasar modal. STOS memiliki peran sebagai fasilitas atau alat bantu bagi investor yang ingin melakukan transaksi saham secara syariah.

Pada ETF syariah, index syariah merupakan suatu acuan. Index syariah terdiri dari perusahaanperusahaan yang mematuhi syariah. ETF syariah dikelola berdasarkan prinsip dan pedoman syariah atau berdasarkan hukum Islam yang dimana akan diawasi oleh Dewan Pengawas Syariah. Dewan Pengawas Syariah bertugas memastikan bahwa ETF syariah patuh terhadap prinsip-prinsip dan pedoman yang berdasarkan hukum Islam (Farouk \& Masih, 2016). Investor muslim akan cenderung memperhatikan apakah produk investasi tersebut terbebas dari riba atau interest.

Berdasarkan data Bursa Efek Indonesia (2020d) ada beberapa point yang perlu menjadi perhatian pada ETF konvensional, yaitu: (1) portofolio yang tidak sesuai dengan syariah; (2) tracking indeks yang tidak sesuai dengan syariah; (3) Screening syaraih yang gagal; (4) derivatif; (5) Melakukan Pinjaman Efek. ETF konvensional terdiri dari underlying assets yang tidak sesuai dengan syariah. Portofolio ekuitas yang tidak melalui proses screening pada portofolio ETF tidak dapat lolos dalam tahap screening bisnis. Investor muslim akan melihat apakah produk tersebut memiliki leverage yang berlebihan dan interestbearing debt, dengan adanya hal tersebut dapat dikatakan tidak sesuai dengan syariah dalam bagian keuangan.

ETF obligasi adalah aset yang keberadaanya tidak sesuai dengan syariah, ini dikarenakan adanya jaminan utang yang dimana menggunakan dasar pinjaman dengan bunga. Obligasi merupakan kewajiban hutang yang dimana penerbit akan membayar tingkat pengembalian yang telah ditentukan sebelumnya kepada pemegang obligasi. Dalam hal ini tidak adanya investasi pada underlying assets, sebaliknya penerbit obligasi memiliki hak dan kewajiban kepada pemegang obligasi. Untuk obligasi pembayaran yang efektif adalah menggunakan 'qard' dari perfektif syariah.

Berdasarkan hukum, melakukan tracking indeks yang tidak sesuai dengan syariah tidak melanggar hukum dan tidak membuat investasi tersebut menjadi tidak sesuai dengan syariah. Namun, pada keuangan islam hal itu kontradiktif. Agar Industri keuangan Islam dapat berkembang perlu mengembangkan sistem yang dapat mempertimbangkan segala faktor, lengkap, dan independen. Dewan pengawas syariah menganggap bahwa tracking indeks yang dilakukan tidak sesuai dengan syariah sebagai non-compliant. Adanya hal ini diharapkan dapat membantu industri keuangan syariah untuk mengalami pertumbuhan dan tidak terikat dengan hal-hal yang tidak sesuai dengan syariah. 
Umumnya ETF konvensional tidak dapat dikatakan sebagai ETF syariah dikarenakan pada penyaringan bisnis atau keuangan tidak sesuai syariah. Unsur-unsur didalam bisnis atau keuangan tersebut tidak sesuai dengan syariah. Pada ETF konvensional melakukan investasi pada instrumen keuangan yang tidak sesuai dengan syariah, contohnya seperti swaps, perusahaan finansial dan perusahaan minuman keras. Pada keuangan adanya banyak ekuitas dari ETF konvensional yang tidak sesuai dengan syariah seperti, tingkat hutang yang berlebihan, deposito berbunga, utang berbunga, dan pendapatan yang tidak sesuai dengan syariah.

Dalam portofolio ETF komoditas berisi perjanjian pada masa depan dan swaps. Hal tersebut tidak sesuai dengan syariah. Pada transaksi berjangka, counter-value, tidak adanya barang pada waktu kontrak, dengan adanya hal ini membuat penjualan terjadi secara tidak teratur (fasid). Penjualan yang normal tidak adanya counter-value yang ditunda dalam kontrak, oleh sebab itu transkasi berjangka yang dimana counter value ditunda tidak diperbolehkan dalam syariah. Hal ini dikarenakan merupakan pertukaran antara hutang dengan hutang lainnya.

Hal lain yang cukup terlihat pada ETF konvensional adalah adanya pinjaman efek. Pinjaman efek adalah aktifitas yang dirancang dimana ETF memberikan pinjaman jangka pendek dari underlying saham atau portofolio dalam obligasi. Dalam hal ini dilakukan secara bertahap agar dapat meningkatkan pengembalian bagi pemegang saham. Pinjaman efek umumnya jarang dilakukan secara langsung antara dana dan investor. Manajer investasi akan menggunakan pihak ketiga seperti bank kustodian dan pihak ketiga lain yang kompeten pada bidang tersebut yang dimana memiliki tugas sebagai agen untuk melakukan peminjaman efek kepada para investor. Manajer investasi ETF akan memberikan jaminan pada pasar uang dengan harapan dari hal tersebut akan mendapatkan bunga yang akan digunakan untuk investasi tersebut.

Berdasarkan hukum Islam, melakukan penyimpanan dana pada pasar uang merupakan Qard (pinjaman). Pengembalian atas deposit adalah riba (bunga). Dalam islam pinjaman qard merupakan kontrak yang tidak mengharap adanya pengembalian pada kemudian hari. Dalam syariah dilarang memberikan pinjaman dengan tujuan untuk mendapatkan keuntungan dikemudian hari. Hal ini juga berlaku pada kontrak pinjaman yang dimana tidak diperbolehkan adanya untuk mencari keuntungan. Setiap laba atau pengembalian yang didapatkan tidak diperbolehkan dan hal tersebut tidak sesuai dengan syariah. lembaga yang melakukan pinjaman pada surat berharga ETF yang kemudian membayar fee pada ETF ini merupakan bentuk riba pada ETF.

Secara umum ETF syariah memiliki persamaan dengan ETF konvensional, namun ada beberapa ciriciri yang membuat berbeda, sebagai berikut:

Tabel 4. Perbedaan ETF Konvensional dan Syariah

\begin{tabular}{|l|l|l|}
\hline Ciri-ciri & ETF Syariah & $\begin{array}{l}\text { ETF } \\
\text { Konvensional }\end{array}$ \\
\hline Indeks & $\begin{array}{l}\text { Hanya mengikuti } \\
\text { indeks yang sesuai } \\
\text { syariah. }\end{array}$ & $\begin{array}{l}\text { Mengikuti } \\
\text { indeks yang } \\
\text { diinginkan. }\end{array}$ \\
\hline $\begin{array}{l}\text { Underlying } \\
\text { Efek }\end{array}$ & $\begin{array}{l}\text { Menggunakan } \\
\text { efek yang sesuai } \\
\text { syariah dimana } \\
\text { telah disetujui } \\
\text { oleh komite } \\
\text { syariah pada } \\
\text { tingkat perusahaan } \\
\text { dan regulasi. }\end{array}$ & $\begin{array}{l}\text { Menggunakan } \\
\text { efek yang } \\
\text { berada dalam } \\
\text { kumpulan } \\
\text { indeks. }\end{array}$ \\
\hline $\begin{array}{l}\text { Penggunaan } \\
\text { Efek Sintesis }\end{array}$ & $\begin{array}{l}\text { Tidak diperbolehkan } \\
\text { dian }\end{array}$ & Ya \\
\hline $\begin{array}{l}\text { Syariah } \\
\text { Governance }\end{array}$ & Ya & Tidak \\
\hline
\end{tabular}

Sumber: (MyETF, 2020)

Untuk dapat menjadi ETF syariah akan melalui penyaringan kriteria, secara industri dan rasio keuangan. Fatwa DSN-MUI No: 20/DSNMUI/IV/2001 tentang Pedoman Pelaksanaan Investasi Untuk Reksa dana Syariah pasal delapan (8) ayat satu (1) dan dua (2) menjelaskan bahwa investasi hanya dapat dilakukan pada efek-efek yang kegiatan usahanya tidak bertentangan dengan syariat islam. Kegiatan usaha yang bertentangan dengan syariat islam yaitu usaha perjudian dan dan permainan yang tergolong judi atau perdagangan yang dilarang; Usaha lembaga keuangan konvensional (ribawi); Usaha yang memproduksi, mendistribusi, serta memperdagangkan makanan dan minuman yang haram; dan Usaha yang memproduksi, mendistribusi, dan/atau menyediakan barang-barang ataupun jasa yang merusak moral dan bersifat mudarat. Ketika suatu emiten telah lolos pada tahap penyaringan kriteria secara industri maka tahapan selanjutnya penyaringan rasio keuangan. 
Fatwa DSN-MUI No: 20/DSN-MUI/IV/2001 Pasal sepuluh (10) ayat satu (1) dan dua (2) menjelaskan bahwa suatu emiten tidak layak diinvestasikan oleh Reksa Dana Syariah jika mengandung hal-hal sebagai berikut: (i) apabila struktur hutang terhadap modal sangat bergantung kepada pembiayaan dari hutang yang pada intinya merupakan pembiayaan yang mengandung unsur riba; (ii) apabila suatu emiten memiliki nisbah hutang terhadap modal lebih dari $82 \%$ (hutang $45 \%$, modal $55 \%$ ); dan (iii) apabila manajemen suatu perusahaan diketahui telah bertindak melanggar prinsip usaha yang Islami.

\subsection{Peluang dan Tantangan ETF dan ETF Syariah di Indonesia}

Di Indonesia ETF dan ETF syariah dapat dikatakan akan terus mengalami pertumbuhan di masa depan. Apalagi Indonesia merupakan salah satu negara yang memiliki jumlah penduduk Muslim terbesar di dunia. Hal ini menjadikan Indonesia menjadi negara keempat yang memiliki jumlah penduduk terbesar di dunia. Jumlah penduduk yang besar ini merupakan peluang untuk pasar modal dan pasar modal syariah untuk berkembang. Populasi penduduk yang besar juga merupakan peluang untuk tumbuhnya investor-investor. Hal tersebut merupakan berita positif untuk ETF dan ETF syariah berkembang di masa depan. Berdasarkan data dari Otoritas Jasa Keuangan bahwa pertumbuhan ETF mengalami pertumbuhan pesat dalam lima tahun. Direktur Pengelolaan Investasi Otoritas Jasa Keuangan mengatakan bahwa assets under management reksa dana ETF mengalami pertumbuhan. Pada tahun 2015 jumlah assets under management Reksa Dana ETF sebesar Rp. 2,6 Triliun. Namun, pada 14 November 2019 menjadi Rp.15 Triliun atau mengalami pertumbuhan sebesar 477 persen (CNBC Indonesia, 2019). Berdasarkan berita yang dihimpun dari (Okefinance, 2016) bahwa telah ada salah satu produk ETF yang mencatatkan imbal hasil (return) sebesar 40 persen. Menurut Direktur Perdagangan dan Pengaturan Anggota Bursa Efek Indonesia bahwa return sebesar 40 persen bisa didapatkan dalam waktu satu tahun. Salah satu perusahaan manajer investasi yakni PT Indo Premier Investment Management telah menghimpun dana hingga Rp.1,2 triliun dari ETF. Berdasarkan data Badan Pusat Statistik pada tahun 2010 jumlah penduduk muslim di Indonesia berjumlah sebanyak 207.176.162 juta jiwa atau setara dengan $87,17 \%$ dari total penduduk Indonesia pada tahun 2010. Jumlah penduduk Indonesia yang mayoritas muslim memberikan peluang untuk ETF syariah berkembang dengan baik serta mendapatkan investor. PT Sinarmas Assets Management pada paruh kedua tahun 2019 menerbitkan ETF syariah. Hal tersebut mengindikasikan bahwa ETF syariah akan terus mengalami pertumbuhan.

ETF dan ETF Syariah memiliki beberapa keuntungan salah satunya adalah transparan. ETF dan ETF syariah lebih transparan jika dibandingkan dengan produk investasi lain. Pada produk investasi ETF dan ETF syariah investor dapat mengetahui informasi terkait dengan produk ETF dan sahamsahamnya dapat diakses kapan saja dan dimana saja. Dengan keuntungan ETF dan ETF syariah yang transparan hal ini merupakan peluang untuk menarik minat investor dan investor muslim untuk mengalokasikan dana pada ETF dan ETF syariah. Melihat investor muslim yang telah banyak dan sadar akan keberadaan ETF syariah hal ini mengindikasikan bahwa ETF syariah akan terus berkembang.

Perkembangan ETF dan ETF syariah di Indonesia juga mengalami tantangan. Pertama, literasi terhadap ETF dan ETF syariah (pengetahuan) yang terbatas. Masyarakat indonesia masih tidak mengetahui tentang pasar modal maupun pasar modal syariah. Pengetahuan yang terbatas tentang pasar modal dan pasar modal syariah membuat masyarakat indonesia enggan mengetahui produk investasi apa saja yang terdapat pada pasar modal Indonesia. Hal ini menjadikan kurangnya minat masyarakat Indonesia untuk berkeinginan melakukan investasi pada produkproduk investasi baru, khususnya pada ETF dan ETF syariah. ETF dan ETF syariah merupakan produk investasi yang cukup asing ditelinga masyarakat indonesia. Dapat dikatakan bahwa penelitian yang membahas tentang ETF dan ETF syariah di Indonesia masih belum banyak dilakukan. Terbatasnya produk ETF dan ETF syariah membuat penelitian terhadap ETF dan ETF syariah terutama di Indonesia masih belum banyak dilakukan. Kedua, ETF dan ETF syariah di Indonesia masih di dominasi oleh investor institusi. Hal ini dapat dikatakan belum ideal, seharusnya komposisi antara investor institusi dan investor individu. Ini merupakan tantangan untuk ETF dan ETF syariah menarik minta investor individu.

Ada beberapa tantangan yang dihadapi oleh ETF syariah di Indonesia. Pertama, pada tahun 2020 hanya terdapat tiga ETF syariah di Indonesia. Ini mengindikasikan bahwa ETF syariah masih belum 
dapat berkembang baik di indoneisa, dikarenakan jumlah partisipan yang ingin menerbitkan ETF syariah masih sedikit jika dibandingkan dengan ETF. Kedua, Menurut Prakasa (2012) belum ada fatwa khusus membahas tentang kepatuhan syariah yang dikeluarkan oleh Dewan Syariah Nasional. Dikarenakan ETF diklasifikasikan sebagai reksa dana maka dicakup dalam Fatwa DSN-MUI No: 20/DSNMUI/IV/2001 tentang Pedoman Pelaksanaan Investasi Untuk Reksa dana Syariah. Sedangkan untuk perdagangan ETF syariah dicakup oleh Fatwa DSNMUI No. 80/DSN-MUI/III/2011 tentang Penerapan Prinsip Syariah dalam Mekanisme Perdagangan Efek Bersifat Ekuitas di Pasar Reguler Bursa Efek. Dengan belum adanya Fatwa khusus yang membahas tentang kepatuhan syariah serta Peraturan yang membahas seperti apa produk ETF syariah hal ini mengindikasikan akan menyulitkan para investor muslim.

Ketiga,tantangan lainnya yang dihadapi oleh ETF syariah adalah bahwa investor ETF syariah tidak memiliki akses ke produk investasi lainnya hal ini dikarenakan adanya pembatasan dan kurangnya sponsor akan produk ETF syariah karena ETF syariah merupakan produk baru (Diaw, Hassan, \& Ka, 2010). ETF konvensional diperbolehkan adanya pinjam meminjam surat berharga dengan bunga, namun pada ETF syariah hal tersebut tidak diperbolehkan, dikarenakan adanya bunga (riba). Bursa Efek Malaysia melakukan inovasi menyangkut hal tersebut dengan untuk pinjam meminjam efek akan menggunakan struktur wand (janji yang dilakukan sepihak) untuk mendukung penciptaan ETF syariah dan memastikan bahwa kepemilikan saham sesuai dengan syariah. Adanya hal ini merupakan memberikan solusi bagi lembaga keuangan untuk mengembangkan dan menawarkan ETF syariah kepada invetor global (Diaw et al., 2010).

Keempat, ETF syariah juga menghadapi tantangan bahwa kurang adanya dukungan dari pemerintah terkait ETF syariah. Hal ini merupakan sesuatu yang cukup penting, dikarenakan agar para investor mengetahui bagaimana transaksi yang sesuai dengan syariah dan tidak melanggar kepatuhan syariah. Perlu adanya dukungan aktif dari pemerintah dalam bentuk kebijakan-kebijakan dan insentif yang sesuai untuk mengembangkan pasar modal dan produk investasi yang sesuai dengan syariah (Prakasa, 2012).
Pertumbuhan ETF syariah di Indonesia belum berkembang, hal ini ditunjukkan dengan hanya terdapat tiga ETF syariah pada Bursa Efek Indonesia. Ketiga ETF syariah tersebut memiliki underlying berupa saham. Ini merupakan tantangan untuk mengembangkan ETF syariah di Indonesia.

\section{KESIMPULAN}

ETF dan ETF syariah merupakan salah satu produk investasi yang cukup menarik dan unik. ETF adalah Reksa Dana yang berbentuk Kontrak Investasi Kolektif. ETF merupakan produk investasi dapat diperjual beli selama jam bursa berlangsung. Sampai dengan saat ini ETF dan ETF syariah masih akan terus berkembang secara global dan Indonesia. Dikarenakan ETF memiliki beberapa keuntungan. ETF sendiri merupakan produk yang transparan, ini merupakan salah satu kelebihan dari ETF dibandingkan produk investasi lainnya.

Dengan masyarakat Indonesia yang mayoritas muslim hal ini merupakan peluang berkembangnya ETF syariah. Melihat ETF syariah di Indonesia semakin berkembang dan mengalami peningkatan ini merupakan sinyal positif. Namun, masih ada tantangan dari ETF syariah sendiri di Indonesia. Kurangnya regulasi dari pemerintah dan pengetahuan akan pasar modal yang masih sangat sedikit diketahui oleh masyarakat Indonesia dan itu merupakan tantangan untuk perkembangan ETF di Indonesia.

\section{UCAPAN TERIMA KASIH}

Penulis mengucapkan terima kasih kepada Jurusan Akuntansi dan Program Magister Akuntansi (MAKSI) Fakultas Bisnis dan Ekonomika (FBE) Universitas Islam Indonesia yang telah memberikan kesempatan untuk dapat menyelesaikan paper ini dengan baik. Semoga paper ini dapat menjadi wawasan baru pengembangan instrumen keuangan syariah di Indonesia melalui pasar modal syariahnya.

\section{REFERENSI}

Bahrain, S. A. L. by T. C. B. of. (2018). Solving The Dynamic of Shariah in ETFS \& ETNS. Retrieved from https://shariyah.com/wpcontent/uploads/2019/07/Solving-the-Dynamicsof-Shariah-in-ETFs-ETNs-Dis.pdf. 


\section{Jurnal Ilmiah Ekonomi Islam, 7(01), 2021, 66}

Barclays. (2019). An introduction to Exchange Traded Funds (ETFs). Retrieved from https://www.barclays.co.uk/smart-

investor/investments-explained/funds-etfs-andinvestment-trusts/introduction-to-exchangetraded-funds-etfs/

Bursa Efek Indonesia (2020a). Exchange Traded Funds. Retrieved November 10, 2019, from Bursa Efek Indonesia website: https://www.idx.co.id/produk/exchange-tradedfund-etf/

Bursa Efek Indonesia (2020b). Pengantar Pasar Modal. Retrieved from https://www.idx.co.id/investor/pengantar-pasarmodal/

Bursa Efek Indonesia (2020c). Produk Syariah. Retrieved November 20, 2020, from https://www.idx.co.id/idx-syariah/produksyariah/

Bursa Efek Indonesia (2020d). Data Exchange Traded Fund (ETF). Retrieved January 16, 2020, from https://www.idx.co.id/data-pasar/data-exchangetraded-fund-etf/

Diaw, A., Hassan, S., \& Ka, A. N. B. (2010). Performance of Islamic and Conventional Exchange Traded Funds in Malaysia. ISRA International Journal of Islamic Finance, 2(1), 131-149.

Farouk, F., \& Masih, M. (2016). Are there profit (returns) in Shariah-compliant exchange traded funds? The multiscale propensity. Research in International Business and Finance, 38, 360375.

Fatwa Dewan Pengawas Syariah No:20/DSNMUI/IV/2001 Tentang Pedoman Pelaksanaan Investasi Untuk Reksa Dana Syariah.

CNBC Indonesia (2019). Dana Kelolaan Reksa Dana ETF Melonjak 5 Tahun, Apa Pemicunya? Retrieved from CNBC Indonesia website: https://www.cnbcindonesia.com/investment/201 91120162354-21-116669/dana-kelolaan-reksadana-etf-melonjak-5-tahun-apa-pemicunya
Kumparan. (2019). Investor Pasar Modal RI Capai 2,48 Juta Orang. Retrieved January 5, 2020, from https://kumparan.com/kumparanbisnis/investorpasar-modal-ri-capai-2-48-juta-orang1sXr7D8QAnS/full

MyETF. (2020). Islamic vs. Conventional ETF. Retrieved March 5, 2020, from https://www.myetf.com.my/en/UnderstandingETF/EFT-Advanced/Islamic-ETF/Islamic-vsConventional-ETF

Neuman, W.L., Djamba, Y.K. (2014). Social Research Methods: Qualitative and Quantitative Approaches. 7th ed. USA: Pearson.

Okefinance (2016). Imbal Hasil Produk ETF Dinilai Menjanjikan. Retrieved November 11, 2019, from

https://economy.okezone.com/read/2016/10/21/ 278/1521071/imbal-hasil-produk-etf-dinilaimenjanjikan

Otoritas Jasa Keuangan (2018). Laporan Perkembangan Keuangan Syariah Indonesia. Jakarta: OJK.

Peraturan OJK No.19/POJK.14/2015 Tentang Penerbitan dan Persyaratan Reksa Dana Syariah.

Peraturan OJK No.49/POJK.04/2015 Tentang Reksa Dana Berbentuk Kontrak Investasi Kolektif Yang Unit Penyertaannya Diperdagangkan Di Bursa Efek,

Prakasa, Y. (2012). The Potential for Islamic Exchange Traded Fund (ETF) in Indonesia : A Comparative Study of Development in US, UK, and Malaysia. (June), 1-36. https://doi.org/10.13140/RG.2.2.14290.96960 